\title{
PENGEMBANGAN VIDEO PEMBELAJARAN MATA KULIAH TEKNOLOGI PENGAWETAN MAKANAN MATERI KACANG DISKO
}

\author{
Andian Ari Anggraeni ${ }^{1}$, Mutiara Nugraheni ${ }^{2}$, Titin Hera Widi Handayani ${ }^{3}$ \\ ${ }^{1,2,3}$ Program Studi Pendidikan Teknik Boga Universitas Negeri Yogyakarta \\ Email: andian_ari@uny.ac.id
}

\begin{abstract}
ABSTRAK
Penelitian ini bertujuan mengembangkan video pembelajaran yang layak pada mata kuliah Teknologi Pengawetan Makanan materi pembuatan kacang disko. Penelitian ini adalah penelitian pengembangan. Video dikembangkan dengan pendekatan 4D, yaitu define, design, develop dan disseminate. Pengumpulan data menggunakan angket penilaian kelayakan media. Subyek penelitian 1 orang ahli materi, 1 orang ahli media dan 30 orang calon pengguna yaitu mahasiswa program studi Pendidikan Teknik Boga, Universitas Negeri Yogyakarta. Hasil penelitian menunjukkan bahwa video dikembangkan dengan format mp4, durasi 11 menit. Video ini terdiri dari 5 bagian yaitu pembukaan, persiapan alat dan bahan, proses produksi, uji kadaluarsa dan penutupan. Dan menggunakan format presenter di bagian pembukaan dan penutupan. Bagian persiapan, produksi, dan uji kadaluarsa dipandu oleh suara dubber dan diperagakan oleh talent mahasiswa. Video diunggah dalam YouTube channel Pendidikan Teknik Boga Universitas Negeri Yogyakarta dengan URL https://youtu.be/ne7981MDqbY. Prosentase kelayakan video berdasar ahli materi $97 \%$, ahli media $89 \%$ dan calon pengguna $79 \%$ yang semuanya masuk kategori sangat layak. Oleh karena itu, video kacang disko ini dinyatakan sangat layak untuk digunakan sebagai media pembelajaran pada mata kuliah Teknologi Pengawetan Makanan.
\end{abstract}

Kata Kunci: kacang disko, video pembelajaran PENDAHULUAN

Metode pembelajaran konvensional atau tradisional biasanya disampaikan dengan metode ceramah. Saat pertemuan tatap muka langsung di dalam kelas, dosen akan menyampaikan materi dengan cara ceramah menggunakan software presentasi atau menunjukkan video pembelajaran. Dosen menjadi satu-satunya sumber ilmu pengetahuan. Kemudian mahasiswa akan mendengarkan penjelasan dosen, memperhatikan dan mencatat hal-hal penting. Metode pembelajaran tradisional merupakan teacher centered learning (TCL). Metode pembelajaran TCL akhir-akhir ini sudah mulai ditinggalkan. Hal ini disebabkan karena working memory mahasiswa terbatas untuk memproses dan menyimpan informasi baru. Ketika kapasitas working memory mahasiswa sudah terlewati, maka kegiatan pembelajaran menjadi terganggu [3]. Metode TCL dapat digunakan apabila dosen adalah seorang pembicara yang baik, pesan yang disampaikan berupa informasi, dan jumlah mahasiswa terlalu banyak.

Pengetahuan yang ada dalam diri manusia merupakan konstruksi (bentukan) dari diri sendiri, dibentuk ketika individu melakukan interaksi dengan lingkungannya. Teori pembelajaran konstruksivisme didukung oleh Piaget melalui teori perkembangan kognitif yang berpendapat bahwa pengetahuan tidak boleh diperoleh secara pasif akan tetapi harus secara aktif melalui tindakan [9].

Alternatif lain untuk pendekatan pengajaran adalah student centered learning (SCL). Pendekatan SCL akan memberi fasilitas kepada mahasiswa untuk membentuk sendiri pengetahuannya, sehingga akan diperoleh pengetahuan yang mendalam dan berkualitas.

Saat ini, pendekatan TCL mulai digantikan dengan pendekatan SCL. Orientasi TCL berbeda dengan SCL. Orientasi strategi TCL adalah konten (content oriented). Sedangkan orientasi strategi SCL adalah pembelajaran (learning oriented), yaitu proses kegiatan 
belajar oleh mahasiswa. Oleh karena itu, peran dosen pada pembelajaran SCL bergeser menjadi fasilitator yang menyediakan aneka jenis sumber belajar, motivator, serta moderator dan penasehat dalam proses diskusi. Sebagai fasilitator, dosen tidak hanya menyediakan berbagai jenis media pembelajaran, tetapi juga harus mendesain strategi belajar yang memungkinkan mahasiswa untuk menciptakan pengetahuannya sendiri.

Proses belajar mengajar pada umumnya melibatkan dua jenis aktivitas, yaitu aktivitas di dalam kelas dan aktivitas di luar kelas. Pada metode tradisional, saat aktivitas di dalam kelas, dosen akan menyampaikan materi dengan cara ceramah. Kemudian dosen akan memberi tugas, baik tugas individu maupun tugas kelompok, untuk dilakukan di luar kelas. Flipped classroom adaah model pembelajaran yang membalik pembelajaran tradisional, yaitu membalik kegiatan ceramah dan tugas.

Pada pembelajaran flipped classroom, kegiatan pembelajaran diawali dengan ativitas di luar kelas. Sebelum datang ke kelas, mahasiswa melihat dan mendengarkan ceramah dosen melalui bantuan internet, misalnya dengan cara mengakses video dosen mengajar yang diunggah dalam sistem e-learning atau mengakses slide presentasi dosen yang telah dilengkapi dengan suara. Kemudian saat pertemuan langsung mahasiswa dan dosen di kelas, dosen memberikan aktivitas atau tugas untuk dikerjakan di kelas. Aktivitas di dalam kelas ini dapat berupa presentasi, diskusi, bermain peran, project based learning, problem based learning, dan lain sebagainya. Semua aktivitas ini akan melibatkan komunikasi dua arah antara dosen dengan mahasiswa. Dosen berperan sebagai fasilitator atau moderator dalam aktivitas ini. Semua aktivitas ini dapat meningkatkan pemahaman mahasiswa pada materi baru [4].

Pembelajaran dengan pendekatan flipped classroom akan dimulai denganmahasiswa mempelajari materi baru dengan menggunakan video. Keuntungan penggunaan video adalah mahasiswa dapat mempelajari materi baru sesuai dengan kecepatan individu. Mahasiswa dapat menghentikan video untuk mencatat informasi baru serta memainkan ulang video untuk melakukan review materi yang masih belum dapat dipahami [2]. Pembelajaran dengan pendekatan flipped classroom merupakan salah satu strategi yang mendukung SCL.

Pelaksanaan pembelajaran dengan pendekatan flipped classroom membutuhkan dukungan media pembelajaran yang sesuai. Media pembelajaran yang paling mendukung pendekatan flipped classroom adalah video. Penjelasan atau ceramah dosen direkam dalam bentuk video. Karakteristik video pembelajaran menurut menurut [5] adalah: bahasa sederhana dan mudah dimengerti, kejelasan pesan yang akan disampaikan, materi representatif, visualisasi dengan media teks, animasi atau sound, mengggunakan kualitas grafis resolusi tinggi, stand alone, dan dapat digunakan secara klasikal atau individual.

Perkembangan teknologi informasi dan komunikasi (TIK) yang pesat dapat digunakan untuk mencapai tujuan pembelajaran. Pemanfaatan TIK dalam pembelajaran memerlukan beberapa kondisi sebagaimana dikemukakan oleh [7] terutama yang berkaitan dengan pemanfaatan internet, yaitu: 1) dosen dan mahasiswa harus mempunyai akses yang mudah ke perangkat teknologi termasuk koneksi internet, 2) tersedia konten digital (bahan ajar) yang mudah dipahami dosen dan mahasiswa, 3) dosen harus mempunyai pengetahuan dan ketrampilan menggunakan teknologi, dan 4) sumber daya guna membantu siswa mencapai standar akademik. Beberapa contoh pemanfaatan TIK dalam pembelajaran yang terjadi saat ini antara lain adalah pemanfaatan program audio pembelajaran, program video pembelajaran, pemanfaatan TVedukasi, pemanfaatan jejaring sosial, dan elearning.

Pendekatan flipped classroom dapat dilakukan dengan bantuan e-learning. Video pembelajaran dapat diunggah atau disematkan dalam sistem e-learning. E-learning juga 
dilengkapi dengan fasilitas quiz dan forum. Sebelum datang ke kelas, mahasiswa dapat diminta untuk melakukan aktivitas dalam elearning, seperti mendengarkan video, mengerjakan quiz dan berdiskusi dalam forum. Sehingga mahasiswa datang ke kelas dalam kondisi sudah memiliki pengetahuan mengenaia apa yang akan dipelajari.

Mata kuliah Teknologi Pengawetan Makanan (TPM) merupakan mata kuliah wajib yang ditempuh pada semester 5 di program studi Pendidikan Teknik Boga. Mata kuliah ini merupakan mata kuliah 2 SKS praktik, yang membahas tentang teori prinsip-prinsip pengawetan, pengemasan, pemasaran dan harga jual, dan praktik pengawetan pada daging (bakso, nugget), ikan (kerupuk ikan, bandeng tanpa duri crispy, bandeng presto), telur (telur asin), susu (soft ice cream), buah (selai, keripik pisang, sari buah), sayuran (mie sayur, saos sambal), serealia (mie telur, garlic snack, sesame snack), kacang-kacangan (sari kedelai, tahu, kacang disko, bumbu pecel), pembuatan permen (soft candy, hard candy, permen jeli), dan pembuatan aneka minuman (teh botol, sirup buah, sirup special grade, sari buah, jahe/kencur/kunyit instan).

Bahan ajar yang digunakan meliputi handout, jobsheet, slide presentasi, dan video pembelajaran. Semua bahan ajar tersebutdiunggah dalam course e-learning TPM di LMS (Learning Management System) milik Universitas Negeri Yogyakarta (UNY) Be Smart v2, yang dapat diakses di http://besmart.uny.ac.id/v2/course/view.php?id $=1310$. Course E-learning TPM juga dilengkapi dengan aktivitas yang berupa quiz. Beberapa bahan kajian dalam mata kuliah ini masih belum dilengkapi dengan video pembelajaran yang layak, salah satunya adalah materi kacang disko.

Penelitian ini bertujuan untuk mengembangkan video pembelajaran yang layak untuk mata kuliah Teknologi Pengawetan Makanan pada materi kacang disko. Video yang sudah dinyatakan layak, kemudian akan diunggah dan disematkan dalam sistem e- learning untuk digunakan sebagai media pembelajaran yang mendukung flipped classroom untuk mencapai pembelajaran SCL.

\section{METODE}

Penelitian ini merupakan jenis penelitian pengembangan (research and development). Pengembangan video pembelajaran menggunakan pendekatan model 4D[8]yaitu 1) Define (pendefinisian), 2) Design (perancangan), 3) Develop (pengembangan) dan 4) Disseminate (penyebarluasan). Prosedur pengembangan video pembelajaran dapat dilihat pada Gambar 1.

Aktivitas yang dilaksanakan pada tahap define adalah identifikasi permasalahan yang terjadi, yang meliputi analisis kondisi saat ini, analisis kondisi ideal yang diinginkan, kesenjangan antara kondisi saat ini dan kondisi ideal, dan prioritas penyelesaian masalah. Setelah itu, akan dilakukan front-end analysis yang meliputi analisis kebutuhan, analisis karakteristik mahasiswa, analisis tujuan, analisis materi dan analisis media.

Aktivitas tahap designmeliputi penyusunanscript video. Script video disusun berdasar materi pembelajaran dalam labsheet. Script video menunjukkan hal-hal yang harus dilakukan saat pengambilan gambar (shooting) dan petunjuk saat proses editing. Script video terdiri dari nomor scene, nomor take, durasi waktu, video, video insert atau animasi, narasi presenter atau dubber, dan lokasi pengambilan video. Kelayakan script video dinilai oleh ahli materi. Revisi script video dilakukan sesuai saran ahli materi. Script video yang dinilai layak dapat diproses lebih lanjut untuk kegiatan shooting (pengambilan gambar). Sebelum dilakukan proses shooting, perlu dilakukan persiapan shooting. Persiapan shooting meliputi pemilihan talent dosen, talent mahasiswa dan dubber. Talent dosen berperan sebagai presenter. Presenter bertugas memberi penjelasan pada bagian pembukaan dan penutupan. Bagian kritis pada proses produksi dan uji kadaluarsa juga dapat dibantu dengan 
penjelasan presenter. Presenter perlu melatih hafalan narasi script, melatih ekspresi supaya mata supaya tetap fokus pada kamera dan melatih ekspresi wajah supaya terlihat ramah di depan kamera. Talent mahasiswa akan melakukan semua kegiatan persiapan, proses produksi dan uji kadaluarsa. Dubber berperan sebagai pengisi suara pada bagian persiapan, proses produksi dan uji kadaluarsa.

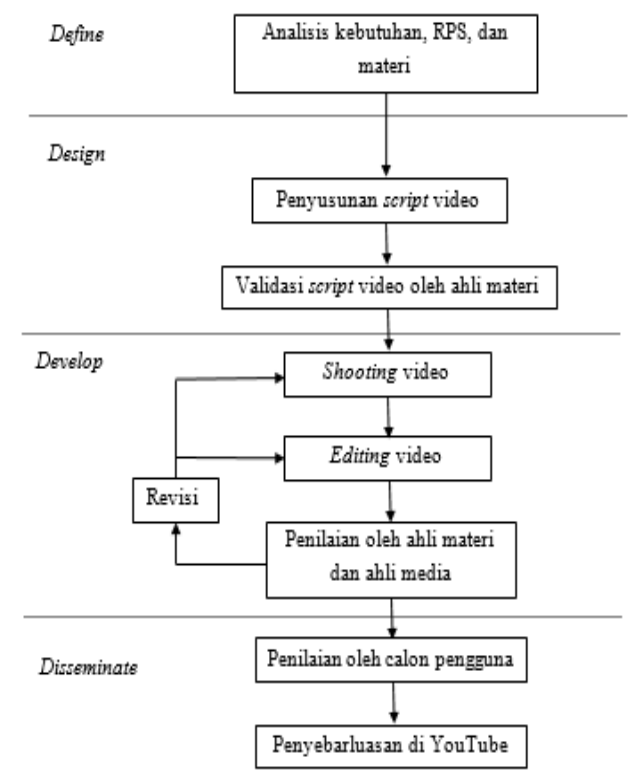

Gambar 1: Prosedur pengembangan penelitian

Aktivitas yang dilakukan pada tahap develop adalah pengambilan gambar (shooting), editing dan revisi video pembelajaran. Pengembangan video pembelajaran merupakan kerjasama dengan LabTV Universitas Negeri Yogyakarta. Shooting indoor kegiatan persiapan, proses produksi dan uji kadaluarsa dilakukan di Laboratorium Kimia Fakultas Teknik (FT), Universitas Negeri Yogyakarta. Sedangan shooting indoor presenter untuk bagian pembukaan dan penutupan dilakukan di studio LabTV, Fakultas Teknik, Universitas Negeri Yogyakarta. Editing video dilakukan oleh editor dari LabTV Universitas Negeri Yogyakarta. Editing video dilakukan untuk menyusun scene pengambilan gambar yang terpisah-pisah. Untuk mengurangi kebosanan mahasiswa saat melihat video, perlu dilakukan variasi scene, terutama pada scene presenter. Variasi scene dilakukan dengan penambahan teks, gambar atau animasi.Video pembelajaran yang sudah selesai proses editing kemudian dilakukan review dan disesuaikan dengan script. Apabila terdapat ketidaksesuaian urutan dengan yang tertulis di script, atau kesalahan editing lainnya, maka dilakukan proses revisi video, sehingga video dinyatakan layak untuk diuji-coba. Video pembelajaran kemudian dinilai kelayakannya oleh ahli materi dan ahli media. Apabila diperlukan, video direvisi berdasar masukan dari ahli materi dan ahli media. Revisi dapat berupa pengambilan gambar ulang untuk adegan yang dianggap kurang tepat atau proses editing ulang.

Aktivitas yang dilakukan pada tahap disseminate adalah penyebarluasan video secara terbatas kepada calon pengguna, yaitu 30 mahasiswa Pendidikan Teknik Boga, FT UNY. Calon pengguna diminta untuk menilai kelayakan video. Video yang dinyatakan layak sebagai media pembelajaran kemudian diunggah di YouTube channel Pendidikan Teknik Boga UNY supaya dapat digunakan oleh masyarakat umum. Video kemudian disematkan pada e-learning Teknologi Pengawetan Makanan.

\section{Metode pengumpulan data}

Pengumpulan data dilakukan dengan menggunakan angket uji kelayakan produk. Terdapat 3 jenis angket, yaitu angket penilaian ahli materi, angket penilaian ahli media dan angket penilaian calon pengguna. Penilaian uji kelayakan menggunakan skala Likert dengan kisaran 1 - 4, yaitu sangat tidak layak (1) sampai dengan sangat layak (4). Data kemudian dianalisis secara kuantitatif. Persentase kelayakan dalam skala Likert dihitung dengan rumus yang diadaptasi dari [6]:

\section{Tingkat kelayakan $=\frac{\sum \text { total skor }}{\text { total skor ideal }} \times 100 \%$}

Tabel 1 menunjukan persentase skala Likert yang didapat dari pengkategorian data kualitatif skala 4. Video pembelajaran 
dinyatakan layak sebagai media pembelajaran jika persentasi penilaian minimal 50,1\%.

Tabel 1: Kategori skala persentase penilaian (Sugiyono, 2016:137).

\begin{tabular}{|l|l|}
\hline Persentase & Kriteria \\
\hline \hline $75,1 \%-100 \%$ & Sangat layak \\
\hline $50,1 \%-75 \%$ & Layak \\
\hline $25,1 \%-50 \%$ & Kurang layak \\
\hline $0 \%-25 \%$ & Tidak layak \\
\hline
\end{tabular}

\section{HASIL DAN PEMBAHASAN}

\section{Tahap Define}

Teknologi Pengawetan Makanan merupakan mata kuliah 2 SKS praktik yang wajib ditempuh pada semester 5 di program studi Pendidikan Teknik Boga. Berdasar hasil observasi dosen, mahasiswa kadang kurang persiapan untuk mengikuti kegiatan praktik, sehingga menyebabkan berkurangnya sikap keaktifan dan kemandirian saat sedang praktik.

Oleh karena itu, sejak tahun ajaran 2016/2017, pembelajaran mata kuliah TPM dilakukan dengan pendekatan flipped classroom menggunakan bantuan e-learning untuk meningkatkan kemandirian dan keaktifan mahasiswa. Media pembelajaran yang selama ini digunakan adalah handout, jobsheet, slide presentasi dan video pembelajaran. Semua media pembelajaran ini diunggah dalam course e-learning TPM. Sebelum datang ke Laboratorium Kimia, mahasiswa diminta untuk membaca jobsheet, melihat video, dan mengerjakan quiz.

Kemudian mahasiswa datang ke Laboratorium Kimia untuk melakukan praktik pada pertemuan tatap muka langsung. Praktik kuliah TPM dilakukan dengan model pembelajaran kelompok dengan menggunakan pembelajaran kooperatif tipe Jigsaw. Mahasiswa dibagi secara acak dalam kelompok kecil yang terdiri dari 3 orang, yang disebut dengan si A, si B dan si C. Satu kelas praktik terdiri dari maksimal 20 mahasiswa, sehingga satu kelas terdiri dari 6-7 kelompok. Kemudian si A sebanyak 6-7 orang akan bergabung dalam grup A. Setiap grup terdiri dari 6-7 mahasiswa. Terdapat 3 grup dalam satu kelas, yaitu grup A, grup B dan grup C. Pada saat praktik, setiap grup mengerjakan produk yang berbeda. Setelah praktik selesai, setiap grup akan mempresentasikan hasil kerjanya di depan kelas. Diskusi juga dilakukan dalam kelompok kecil. Oleh karena itu, grup yang tidak mengerjakan produk tersebut diharapkan menjadi memahami proses praktik grup lain. Namun berdasar observasi dosen, mahasiswa kadang tidak memahami presentasi grup lain dan diskusi kelompok.

Mahasiswa saat ini menyukai media pembelajaran audio visual yang berupa video. Apabila mahasiswa membutuhkan sumber belajar, maka mahasiswa akan memprioritaskan melakukan pencarian video pembelajaran di YouTube. Mahasiswa pada era ini adalah mahasiswa yang gemar mencari sumber belajar sendiri dengan menggunakan bantuan internet.

Berdasar analisis masalah dan analisis kebutuhan tersebut, pembelajaran di mata kuliah TPM dirancang dengan pendekatan flipped classroom. Media pembelajaran diunggah dalam sistem e-learning. Sebelum datang ke kelas, mahasiswa diminta untuk mengakses media pembelajaran dan mengerjakan quiz. Apabila nilai quiz mencapai 7, maka mahasiswa dapat datang ke kelas untuk mengikuti praktik. Apabila nilai quiz belum mencapai 7, maka mahasiswa diminta untuk mengerjakan remidi quiz sampai tercapai standar minimal. Oleh karena itu, mahasiswa datang ke kelas dalam kondisi sudah mengerti apa yang akan dipelajari dan siap untuk melakukan praktik.

Pendekatan flipped classroom memerlukan dukungan media pembelajaran. Ada beberapa bahan kajian mata kuliah TPM yang masih belum dilengkapi dengan video pembelajaran, salah satunya materi kacang disko. Video pembelajaran kacang disko yang selama ini digunakan adalah video open sources yang dapat digunakan secara bebas di YouTube, dan tidak sesuai dengan standar jobsheet mata kuliah TPM. 


\section{Tahap Design}

Jobsheet mata kuliah TPM yang sesuai dengan Rencana Pembelajaran Semester (RPS) mata kuliah TPM sudah disusun pada semestar gasal tahun ajaran 2016/2017. Jobsheet ini kemudian disusun menjadi script video. Kelayakan script video dinilai oleh ahli materi. Ahli materi menyatakan bahwa script video layak dan dapat digunakan untuk proses shooting.

\section{Tahap Develop}

Aktivitas yang dilakukan pada tahap develop adalah pengambilan gambar dan proses editing. Video terdiri dari 5 bagian, yaitu pembukaan, persiapan alat dan bahan, proses produksi, uji kadaluarsa dan penutupan. Durasi setiap bagian dapat dilihat pada Tabel 2 .

Tabel 2: Durasi bagian dalam video kacang disko

\begin{tabular}{|l|l|}
\hline Bagian & Waktu \\
\hline \hline Pembukaan & $0: 00-1: 40$ \\
\hline Persiapan & $1: 41-3: 01$ \\
\hline Proses produksi & $3: 02-7: 42$ \\
\hline Uji kadaluarsa & $7: 43-9: 28$ \\
\hline Penutupan & $9: 29-11: 00$ \\
\hline
\end{tabular}

Pada bagian pembukaan, video dibuka dengan animasi yang berisi identitas nama universitas, fakultas, program studi, nama mata kuliah dan judul video. Bagian pembukaan disampaikan oleh presenter. Proses shooting bagian pembukaan dilakukan secara indoor dengan menggunakan background warna krem dan lighting menggunakan 2 buah lampu warna kuning.

Bagian pembukaan ditunjukkan pada Gambar 2. Presenter menyapa mahasiswa dan menyampaikan capaian pembelajaran pada video. Presenter menjelaskan tentang keunggulan kacang, kelemahan kacang, produk olahan kacang, prinsip pengawetan kacang disko dan pengemasan kacang disko.

Supaya mahasiswa fokus kepada presenter, maka pengambilan gambar presenter dilakukan zoom dari bagian kepala sampai dengan pinggang. Intonasi suara diatur supaya tidak terlalu cepat dan artikulasi suara harus jelas, supaya mahasiswa memahami materi pada video ini. Kemudian ekspresi wajah juga alami, tidak tegang, mata fokus ke kamera dan bibir tersenyum. Gerakan tangan juga dijaga supaya terlihat natural.

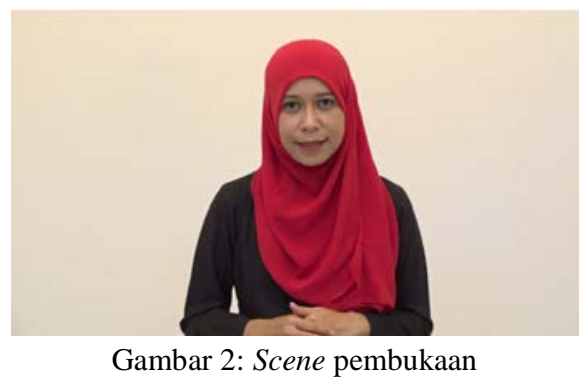

Penjelasan presenter dilengkapi dengan teks dan gambar supaya mahasiswa mudah memahami materi video. Saat presenter sedang menjelaskan suatu materi, maka teks yang berisi kata kunci materi tersebut dapat masuk ke dalam scene (Gambar 3). Saat presenter sedang menjelaskan suatu materi, gambar materi tersebut juga dapat masuk ke dalam scene (Gambar 4). Scene presenter yang dilengkapi dengan teks, gambar atau animasi dapat mencegah kebosanan saat mahasiswa melihat video tersebut.

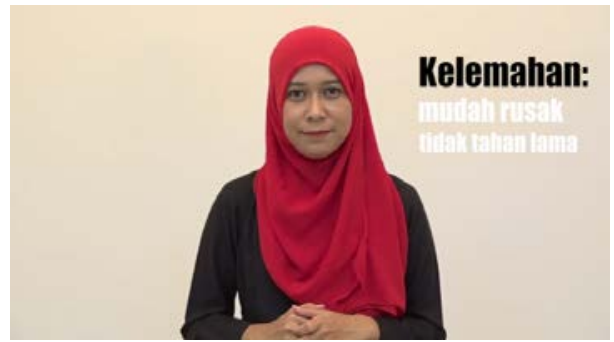

Gambar 3: Scene presenter dengan variasi teks

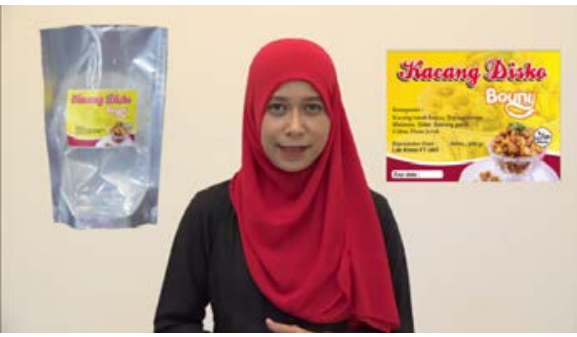

Gambar 4: Scene presenter dengan variasi gambar

Bagian persiapan alat dan bahan diperagakan oleh talent mahasiswa dan panduan narasi dubber. Dubber menyebutkan nama alat/bahan dan talent mahasiswa menunjukkan alat/bahan tersebut. Teks nama alat dan teks nama bahan dan jumlah takarannya juga disertakan pada bagian bawah. 
Proses shooting dilakukan secara indoor di Laboratorium Kimia, dengan menggunakan background sketsel kayu dan bambu. Gambar 5 dan 6 menunjukkan scene persiapan alat dan bahan.

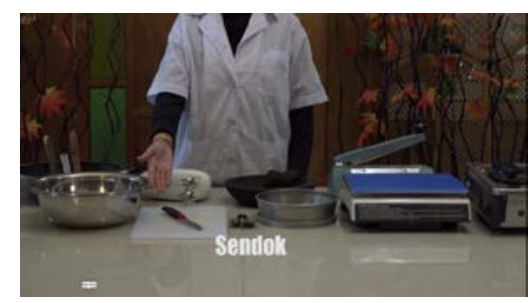

Gambar 5: Scene persiapan alat

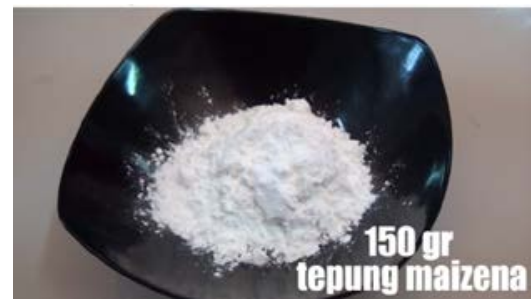

Gambar 6: Scene persiapan bahan

Bagian akhir scene persiapan dilengkapi dengan daftar alat atau daftar bahan yang digunakan, seperti yang dapat dilihat pada Gambar 7.

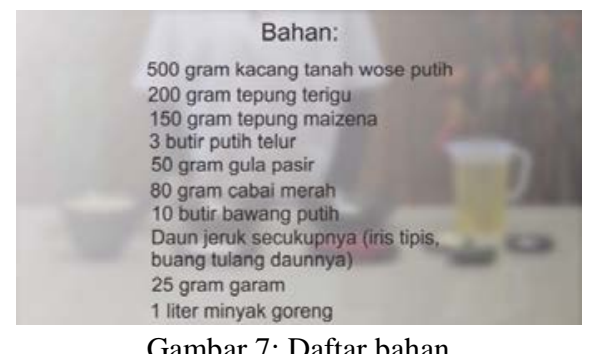

Bagian proses produksi dipandu oleh talent mahasiswa dan dubber. Gambar 8 menunjukkan scene proses produksi. Talent mahasiswa memeragakan kegiatan proses produksi. Dubber menjelaskan langkah-langkah proses yang diperagakan oleh talent mahasiswa. Proses pengambilan gambar dilakukan dari jarak jauh seperti pada Gambar 8, dengan background sketsel kayu dan bambu untuk membatasi fokus. Apabila proses produksi dianggap kritis, maka pengambilan gambar akan dilakukan dari jarak dekat (Gambar 9). Dubber menjelaskan tentang proses yang kritis tersebut. Apabila diperlukan, bagian proses produksi juga diberi tambahan scene presenter yang akan menjelaskan proses produksi yang kritis tersebut (Gambar 10).

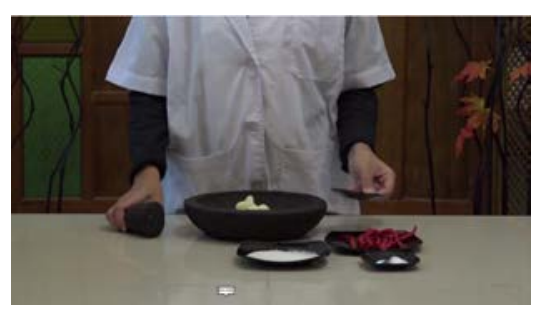

Gambar 8: Scene proses produksi

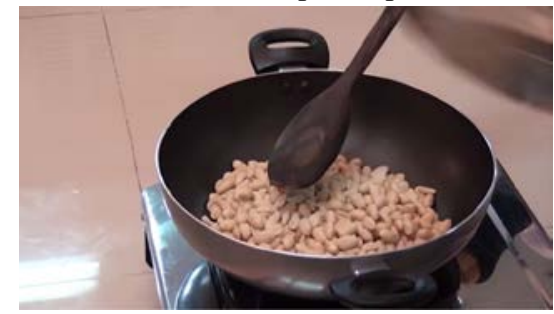

Gambar 9: Zoom gambar pada proses kritis

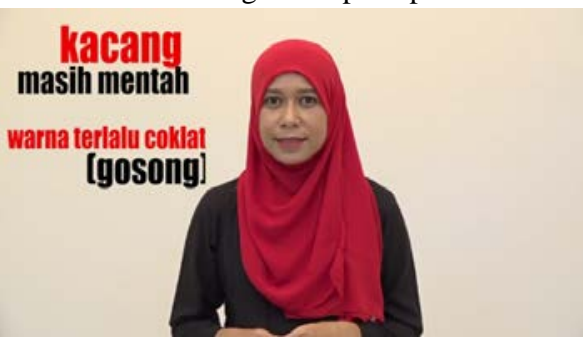

Gambar 10: Penjelasan presenter pada titik kritis proses produksi

Setelah produk selesai diproduksi, tahap selanjutnya adalah proses penentuan waktu kadaluarsa. Bagian ini diperagakan oleh talent mahasiswa dan dubber. Waktu kadaluarsa ditentukan dengan uji organoleptik, seperti yang dapat dilihat pada Gambar 11.

Saat melakukan uji organoleptik, mahasiswa mengisi tabel uji organoleptik. Semua tabel yang digunakan pada uji organoleptik juga disertakan dalam video ini (Gambar 12). Mahasiswa harus menentukan kapan produk akan kadaluarsa. Ilustrasi penentuan saat produk kadaluarsa juga disertakan dalam video ini (Gambar 13).

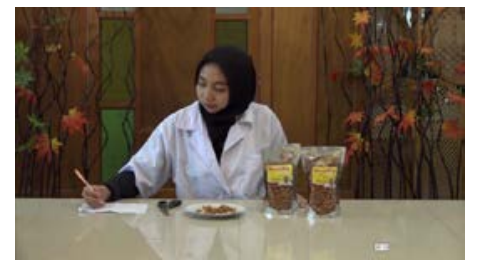

Gambar 11: Uji organoleptik untuk penentuan waktu kadaluarsa produk 


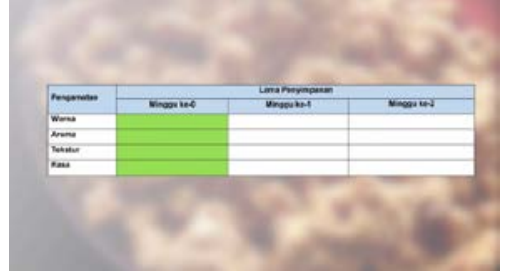

Gambar 12: Tabel uji organoleptik

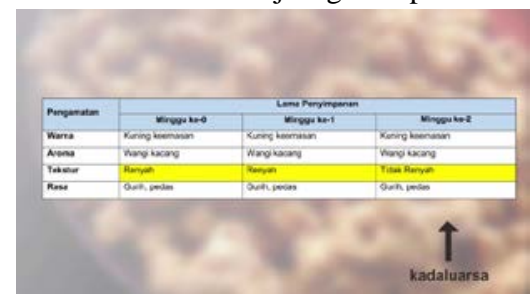

Gambar 13: Ilustrasi penentuan waktu kadaluarsa produk

Produk kacang disko akan kadalursa ketika aroma menjadi tengik dan tekstur menjadi tidak renyah. Mahasiswa perlu memahami faktorfaktor yang menyebabkan produk kacang disko menjadi tengik atau tidak renyah. Untuk mempermudah visualisasi, presenter memberi penjelasan penyebab kadaluarsa kacang disko dengan bantuan animasi penyebab ketengikan kacang disko (Gambar 14) dan animasi penyebab ketidakrenyahan kacang disko (Gambar 15).

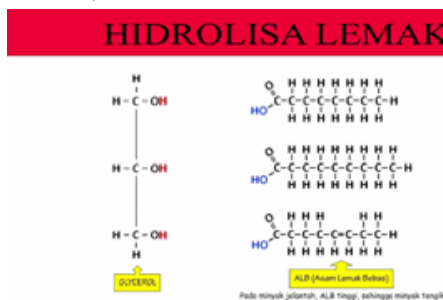

Gambar 14: Animasi penyebab ketengikan kacang disko

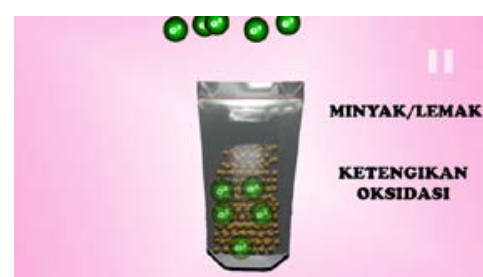

Gambar 15: Animasi penyebab ketidakrenyahan kacang disko

Video ditutup oleh presenter. Presenter memberi semangat kepada mahasiswa supaya dapat melakukan praktik pembuatan kacang disko dengan lancar. Foto-foto yang digunakan pada video ini adalah foto milik pribadi dan foto open source yang tersedia di internet. Foto open source disertakan link URL original source pada bagian penutupan.
Kelayakan video dinilai oleh ahli materi dan ahli media. Aspek yang dinilai oleh ahli materi meliputi pembelajaran, materi, manfaat dan kemudahan penggunaan. Sedangkan aspek yang dinilai oleh ahli media meliputi media, kecocokan video sebagai media pembelajaran SCL, manfaat dan kemudahan penggunaan. Kelayakan video dapat dilihat pada Tabel 3 dan 4. Revisi dilakukan berdasar masukan dari ahli materi dan ahli media.

Tabel 3: Kelayakan video berdasar ahli materi

\begin{tabular}{|l|r|l|}
\hline Aspek & $\begin{array}{r}\text { Prosentase } \\
\text { Kelayakan }\end{array}$ & Kategori \\
\hline Pembelajaran & $93 \%$ & Sangat layak \\
\hline Materi & $98 \%$ & Sangat layak \\
\hline Manfaat & $95 \%$ & Sangat layak \\
\hline Penggunaan & $100 \%$ & Sangat layak \\
\hline Total & $97 \%$ & Sangat layak \\
\hline
\end{tabular}

Tabel 4. Kelayakan video berdasar ahli media

\begin{tabular}{|l|r|c|}
\hline Aspek & $\begin{array}{l}\text { Prosentase } \\
\text { Kelayakan }\end{array}$ & Kategori \\
\hline Media & $87 \%$ & Sangat layak \\
\hline Media SCL & $90 \%$ & Sangat layak \\
\hline Manfaat & $83 \%$ & Sangat layak \\
\hline Penggunaan & $96 \%$ & Sangat layak \\
\hline Total & $89 \%$ & Sangat layak \\
\hline
\end{tabular}

\section{Tahap Disseminate}

Video tutorial pembuatan kacang disko diujicoba secara terbatas kepada 30 orang mahasiswa Pendidikan Teknik Boga sebagai calon pengguna. Calon pengguna menilai kelayakan video dari aspek pembelajaran, media, materi, kemanfaatan dan kemudahan penggunaan. Hasil penilaian calon pengguna dapat dilihat pada Tabel 5.

Tabel 5: Kelayakan video berdasar calon pengguna

\begin{tabular}{|l|r|l|}
\hline Aspek & $\begin{array}{c}\text { Prosentase } \\
\text { Kelayakan }\end{array}$ & Kategori \\
\hline Pembelajaran & $81 \%$ & Sangat layak \\
\hline Media & $77 \%$ & Sangat layak \\
\hline Materi & $80 \%$ & Sangat layak \\
\hline Manfaat & $81 \%$ & Sangat layak \\
\hline Penggunaan & $81 \%$ & Sangat layak \\
\hline Total & $79 \%$ & Sangat layak \\
\hline
\end{tabular}

Ahli materi, ahli media dan calon pengguna menyatakan bahwa video ini memiliki kualitas materi sangat layak dan kualitas media sangat layak. Video ini juga sangat layak dalam hal kemanfaatan, kemudahan penggunaan dan kesesuaian sebagai media pembelajaran SCL. Oleh karena itu, 
video ini sangat layak untuk digunakan sebagai media pembelajaran mata kuliah Teknologi Pengawetan Makanan.

Video diunggah di YouTube channel Pendidikan Teknik Boga Universitas Yogyakarta dengan URL https://youtu.be/ ne7981MdqbY. Untuk mempermudah desain flipped-classroom, video disematkan dalam course e-learning Teknologi Pengawetan Makanan. Video ini tidak hanya dapat digunakan oleh mahasiswa Universitas Negeri Yogyakarta tetapi juga oleh masyarakat umum yang melakukan pencarian di mesin pencari YouTube.

\section{SIMPULAN}

Pengembangan video pembelajaran pada mata kuliah Teknologi Pengawetan Makanan untuk materi pembuatan kacang disko dilakukan dengan pendekatan 4D (define, design, develop dan disseminate). Video ini menjelaskan tentang cara pembuatan kacang disko. Video terdiri dari 5 bagian, yaitu pembukaan, persiapan alat dan bahan, proses produksi, uji kadaluarsa dan penutupan. Durasi video adalah 11 menit dengan format mp4. Video diunggah di YouTube Channel Pendidikan Teknik Boga UNY dengan URL https://youtu.be/ne 7981MDqbY. Kelayakan video materi kacang disko menurut ahli materi adalah 97\% sangat layak, ahli media 89\% sangat layak dan calon pengguna $79 \%$ sangat layak. Oleh karena itu, video pembuatan kacang disko dinyatakan sangat layak untuk digunakan sebagai media pembelajaran mata kuliah Teknologi Pengawetan Makanan.

\section{REFERENSI}

[1] Bergmann, J. and Sams, A. (2012) Flip your classroom: Reach every student in every class every day. Eugene, Oregon:
International Society for Technology in Education.

[2] Educause (2012) 7 things you should know about... Flipped classrooms. Educause Learning Initiative. https://net. educause.edu/ir/library/pdf/ELI7081.pdf.

[3] Hamdan, M., McKnight, P., McKnight, K., and Arfstrom, K. (2013) A review of flipped learning: Flipped Learning Network.http://researchnetwork.pearson.c om/wp-conte nt/uploads/LitReview_FlippedLearning1.p $d f$.

[4] Mazur, A.D., Brown, B., and Jacobsen, M. (2015) Learning designs using flipped classroom instruction, Canadian Journal of Learning and Technology, 41(2), 1-26.

[5] Riyana, C. (2007) Pedoman Pengembangan Media Video. Jakarta: P3AI. UPI.

[6] Sugiyono (2016) Metode Penelitian Pendidikan Pendekatan Kuantitatif, Kualitatif, dan R\& D. Bandung: Alfabeta.

[7] Surjono, H.D. and Gafur, A. (2010) Potensi pemanfaatan ICT untuk peningkatan mutu pembelajaran. Cakrawala Pendidikan, Th. XXIX(2):161-175.

[8] Thiagarajan, S., Semmel, D.S., and Semmel, M.I. (1974) Instructional Development for Training Teachers of Exceptional Children, University of Minnesota.

[9]Trianto (2009) Mendesain model pembelajaran inovatif progresif, Jakarta: Kencana Prenada Media Group. 